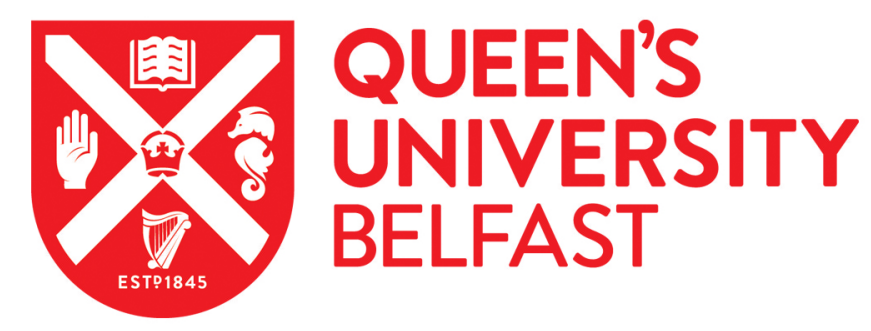

\title{
Innovation in construction firms of different sizes: Drivers and strategies
}

Meng, X., \& Brown, A. (2018). Innovation in construction firms of different sizes: Drivers and strategies.

Engineering Construction and Architectural Management, 25(9), 1210-1225. https://doi.org/10.1108/ECAM-042017-0067

Published in:

Engineering Construction and Architectural Management

Document Version:

Peer reviewed version

Queen's University Belfast - Research Portal:

Link to publication record in Queen's University Belfast Research Portal

Publisher rights

(C2018 Emerald Group Publishing Limited.

This work is made available online in accordance with the publisher's policies. Please refer to any applicable terms of use of the publisher.

\section{General rights}

Copyright for the publications made accessible via the Queen's University Belfast Research Portal is retained by the author(s) and / or other copyright owners and it is a condition of accessing these publications that users recognise and abide by the legal requirements associated with these rights.

Take down policy

The Research Portal is Queen's institutional repository that provides access to Queen's research output. Every effort has been made to ensure that content in the Research Portal does not infringe any person's rights, or applicable UK laws. If you discover content in the Research Portal that you believe breaches copyright or violates any law, please contact openaccess@qub.ac.uk. 


\title{
Innovation in construction firms of different sizes: drivers and strategies
}

\begin{abstract}
Purpose - The importance of innovation has been increasingly highlighted in construction as a large and complex industry sector that is more challenging than ever before. To bridge the knowledge gap about how firm size affects innovation in construction, this research explores firm-level innovation through an empirical investigation and compares innovation in construction firms of different sizes in terms of drivers and strategies.
\end{abstract}

Design/methodology/approach - This research adopts a combination of a literature review, a group of qualitative interviews and a quantitative questionnaire survey. In this research, the questionnaire survey is the main instrument to collect empirical data. Main contractors, subcontractors and specialist contractors as well as suppliers of labor, material and equipment (LME) are used in this research to represent construction firms of different sizes. On the other hand, client organizations, design firms and management consultants are not included in this research.

Findings - This research provides clear evidence for the embrace of innovation in construction. Many forces can drive construction firms to innovate and many strategies can be applied to construction innovation. Innovation drivers can be either internal or external. On the other hand, innovation strategies fall into four categories: technology, resource, marketing and management. For innovation drivers and strategies, both commonalities and differences can be found among construction firms of different sizes.

Originality/value - The finding of commonalities describes the general trend of innovation development in construction. It also encourages all construction firms to innovate regardless of 
firm size. On the other hand, the finding of differences enables construction firms of different sizes to realize what forces better drive their innovation and what strategies are more appropriate for their innovation. A thorough understanding of innovation drivers and strategies offers an important framework for construction organizations and practitioners to pursue best practice.

Keywords Innovation, Driver, Strategy, Construction firm, Firm size

Paper type Research Paper 


\section{Introduction}

According to Pierce and Delbecq (1977) in general and Steele and Murray (2004) in construction, innovation represents the introduction of changes through something new, such as new products, processes, or services. Innovation has drawn widespread attention in today's world (Crossan and Apaydin, 2010). This is because it plays a critical role in enhancing business performance for various organizations, including construction organizations (Panuwatwanich et al., 2008; Kyrgidou and Spyropoulou, 2013). As an important industry sector, construction contributes 5$10 \%$ of gross domestic product (GDP) and is responsible for the majority of fixed capital formation in many countries (Reichstein et al., 2008). Although there is no doubt of its importance to economic growth, construction is generally recognized as a traditional industry sector (Bennett, 2013). It is often criticized for various performance problems, such as low-tech, low productivity, high cost, and less concern for customers/users (Seaden and Manseau, 2001; Dulaimi et al., 2002; Abdel-Wahab et al., 2008; Harty, 2008). Therefore innovation is especially crucial for construction.

Innovation can be divided into three levels: industry-level innovation, firm-level innovation, and project-level innovation. Firm-level innovation links industry-level and project-level innovation. In both general and construction, more existing studies on firm-level innovation can be found compared to those on industry-level and project-level innovation. Construction firms are quite diverse. The vast majority of construction firms are small-sized. This explains why quite a lot of construction studies, such as Davey et al. (2004), Barrett and Sexton (2006), Thorpe et al. (2009), Hardie and Newell (2011) and Shelton et al. (2016), focused their research on innovation in small firms. For example, Davey et al. (2004) evaluated the capacity of action learning to promote innovation for small and medium-sized enterprises (SMEs) in the UK construction 
industry. Hardie and Newell (2011) identified key factors that influence technical innovation in construction SMEs from the Australian perspective. On the other hand, innovation in large firms has drawn research attention from such construction studies as Veshosky (1998) in the United States and Miozzo and Dewick (2002) in five European countries, such as Germany, Sweden, Denmark, France and the UK. They believed that large construction firms play a leading role in the whole industry and represent an important source of innovation.

Small, medium and large firms have different natures. According to Cohen and Klepper (1996) in general and Barrett and Sexton (2006) in construction, innovation patterns for large firms are not necessarily appropriate for small firms, and vice versa. In non-construction sectors, it is possible to find a considerable number of existing studies on the comparison of innovation between firms of different sizes. For example, Wagner and Hansen (2005) identified what small firms differ from large firms in the wood products industry in terms of innovation types. HewittDundas (2006) analyzed resource and capability constraints to innovation in small versus large manufacturing firms. Kumar et al. (2012) examined the similarities and differences for innovation patterns and strategic orientations of small and large firms in the food manufacturing industry. Prajogo et al. (2013) compared innovation orientations and their effects on business performance between small and medium service firms. These comparative studies contribute to a good understanding of innovation in firms of different sizes.

According to an innovation report released by the Organization for Economic Cooperation and Development (OCED), larger firms are more able to afford the investment for innovation and to tolerate the risk of adoption, whereas smaller firms are more likely to value technology and to simplify decision-making processes (OCED, 1982). This is agreed by such construction studies as Tatum (1989) and Nam and Tatum (1997) because smaller firms differ from larger firms in 
terms of goals, resources, capabilities and constraints. In construction, there are a number of research attempts that explore innovation drivers and strategies, which can be seen in the next section of this paper. Some researchers and practitioners have realized the dependence of construction innovation on firm size. For example, Hartmann (2006a) believed that construction firms respond differently to different contexts in terms of innovation and meanwhile identified innovation strength and innovation attractiveness as two contextual variables. On the other hand, Lim et al. (2010) explored how to tailor competitiveness derived from innovation to the needs of construction firms of different sizes. In spite of that, few studies to date have provided empirical evidence to compare innovation among small, medium and large construction firms, especially in terms of both drivers and strategies for innovation. Therefore a gap is identified in the body of existing knowledge.

This research aims to bridge the knowledge gap. Based on a comprehensive review of the literature on general and construction innovation, a group of industrial experts were interviewed and a questionnaire survey was conducted mainly in the construction industry of the United Kingdom (UK) to explore innovation practice in firms of different sizes. The empirical investigation answers the research questions concerning (1) what forces can drive innovation in construction firms of different sizes; (2) what strategies can be adopted by construction firms of different sizes for innovation; (3) whether there are any significant differences for innovation drivers and strategies among small, medium and large firms; (4) whether smaller or larger firms are more innovative; and (5) how to better promote innovation in construction. As a result, it provides deeper insights into construction innovation. The findings of this research are compared with existing literature on general and construction innovation in order to maximize the value of 
this research. Although this research is based on construction innovation, its findings may also be useful for innovation in other industry sectors.

Many participants are involved in a construction project, including project client, design team, management consultant, main contractor, subcontractors, specialist contractors and LME suppliers. According to the Code of Practice for Project Management for Construction and Development released by the Chartered Institute of Building (CIOB), these participants play different roles in a construction project (CIOB, 2010). Project client defines project objectives and requirements. Main contractor, subcontractors and specialist contractors deliver products, whereas design team and management consultant provide services. Suppliers furnish LME. They distinguish from each other. This research is probably the first attempt to explore innovation in construction firms of different sizes. Comparing innovation drivers and strategies between construction firms of different sizes is the focus of this research. It is not necessary to cover all types of project-based organizations at this research stage. For this reason, main contractors, subcontractors and specialist contractors as well as LME suppliers are used in this research to represent construction firms of different sizes for the comparison of innovation drivers and strategies. On the other hand, client organizations, design firms and management consultants are not included in this research.

\section{Drivers and strategies for innovation}

The literature on general and construction innovation reveals that many forces may drive firms to innovate. In general, competitive advantage refers to the ability of an organization/firm to perform at a higher level than others in the same industry/market, which can be achieved through innovation (Porter, 1985; Magretta, 2012). In order to develop advantages over their competitors,

organizations or firms tend to innovate. Four drivers of innovation identified by Goffin and 
Mitchell (2005) are technological advances, changing customers and needs, intensified market competition, and changing business environments. In recent years, changes towards sustainability have been recognized as a key driver of innovation and meanwhile sustainable innovation has become a prominent agenda (Dewick and Miozzo, 2004; Jepsen et al., 2014). Drivers of innovation can be either internal or external (Crossan and Apaydin, 2010). For example, an internal driver can be corporate image (Chang, 2011), whereas an external driver can be market trends and opportunities (Yadav et al., 2007). Generally, innovation should be value-added and value-based (Dringoli, 2009; Gerybadze et al., 2010). However, it is not always the case. This is because innovation in low-tech firms and industries may be cost-driven as opposed to value-driven (Hirsch-Kreinsen and Jacobson, 2008).

In construction, innovation can be stimulated by the new requirements of clients, needs to develop standards, compliances with new regulations, and innovative ideas of research and development (R\&D) staff (Gann and Salter, 2000). Survival, stability and development are identified by Sexton and Barrett (2003) as innovation drivers in construction firms, especially in small construction firms. Cost reduction, competitive advantage, improved quality, and increased productivity can motivate innovation in construction (Gambatese and Hallowell, 2011). According to the CIOB, there are seven drivers of construction innovation: cost efficiency, sustainability, client demands, time constraints, technology, global competition, and end users (CIOB, 2007). A group of construction innovation drivers presented by Bossink (2004) consist of government incentive, technological promotion, integration of design and construction, and so on. Other drivers of innovation identified by construction researchers include: best practice (Yitmen, 2007), customer/user satisfaction (Ozaki, 2003; Wandahl et al., 2011), government 
initiative (Qi et al., 2010), public policy (Seaden and Manseau, 2001), and recession aftermath (Aouad et al., 2010).

Firms may strategize innovation in different manners. In general, internal R\&D and external knowledge acquisition can be considered as two innovation strategies (Cassiman and Veugelers, 2006). Fostering innovation-supportive culture is another general strategy for innovation (Jassawalla and Sashittal, 2002). In construction, the innovation strategies identified by Egbu (2004) include top management support, strategic vision, innovation culture, long-term focus, knowledge sharing and transfer, and education and training. According to Manley and McFallan (2006), introducing new technologies, enhancing technical capabilities, and hiring new graduates are three strategies that are significantly different among clients, contractors, consultants and LME suppliers. In addition, construction researchers have identified some other innovation strategies: action learning (Davey et al., 2004), appropriate response to innovation opportunities and risks (Loosemore, 2014), continuous improvement of performance (Hartman, 2006b), employee engagement in innovation-related activities (Toole et al., 2013), extension of business fields (Barlow, 1999; Gann and Salter, 2000), linking project and business processes (Gann and Salter, 2000), incentive mechanism (Hartmann, 2006b; Leiringer, 2006), proactive attitude towards changes (Hardie and Newell, 2011), quick response to dynamics (Arditi et al., 1997), strategic decision making (Seaden et al., 2003), and strategic management of resources (Sexton and Barrett, 2003).

\section{Research methods}

This research adopts a combination of a literature review, expert interviews and a questionnaire survey. First of all, a comprehensive review of relevant literature helped to obtain the background information about general and construction innovation. It also helped to identify 
drivers and strategies for general and construction innovation. Subsequent to the literature review, approximately ten construction practitioners in the UK were interviewed, who were knowledgeable and experienced in innovation because they had performed innovation-related work, such as development of innovation strategies, for more than five years. They had the organizational backgrounds of main contractors, subcontractors and specialist contractors as well as LME suppliers. Expert interviews revealed the characteristics of innovation in construction. In addition to the confirmation of drivers and strategies identified from the literature review, the interviewees provided additional drivers and meanwhile detailed strategies for construction innovation. For example, they added health and safety $(\mathrm{H} \& \mathrm{~S})$ as a new driver. This reflects the fact that the importance of $\mathrm{H} \& \mathrm{~S}$ has been increasingly highlighted today, especially in construction as an industry sector that faces more H\&S challenges. On the other hand, the interviewees suggested that strategic management of resources identified from the literature review can be further divided into effective use of existing resources, matching resources to strategies, and investment in innovation activities. They believed that knowledge management plays an important role in strategizing construction innovation. According to the interviewees, knowledge exchange and sharing throughout a firm, knowledge exchange and sharing between supply chain partners, and knowledge transfer from universities and other R\&D establishments usually describes three strategies of knowledge-based innovation in construction firms.

Qualitative interviews were followed by a quantitative questionnaire survey. The questionnaire survey is the main methodology in this research. The drivers and strategies identified from the literature review and modified through expert interviews are considered as potential driving forces and strategic options in this research. The main purpose of the questionnaire survey is to explore what potential forces can drive innovation in construction firms of different sizes and 
what potential strategies can be adopted by construction firms of different sizes for innovation. Existing studies on construction firms define firm size using different criteria and establish different thresholds. By comparison, the definition of SMEs by the European Commission (EC) is commonly accepted in Europe and is usually considered more authoritative (EC, 2005). For this reason, it is adopted in the questionnaire to measure the size of a construction firm in terms of the number of its employees. In order to simplify the measurement, this research merges micro firms and small firms and categorizes construction firms into three major groups: (1) micro/small firms (1-49 employees); (2) medium firms (50-249 employees); and (3) large firms (250 or more employees).

There are five sections in the questionnaire: (1) introduction to the purpose and focus of the survey; (2) general information about a respondent and his/her firm; (3) drivers of innovation; (4) strategies for innovation; and (5) additional comments on innovation. This is a firm-specific survey, in which each response refers to innovation practice in a respondent's firm. A total of 20 potential driving forces are provided in Section 3. Each question in Section 3 rates the level of a force that drives innovation in a respondent's firm according to a five-point scale: strongly disagree $(\mathrm{SD}=1)$; disagree $(\mathrm{D}=2)$; neutral $(\mathrm{N}=3)$; agree $(\mathrm{A}=4)$ and strongly agree $(\mathrm{SA}=5)$. Similarly, a total of 23 potential strategic options are provided in Section 4, in which each question rates the level of a strategy that is adopted by a respondent's firm according to a fivepoint scale from SD (=1) to SA (=5). In addition, a respondent is allowed to specify any other drivers and strategies and rate their levels at the end of Sections 3 and 4, respectively.

As a pilot study, a small group of researchers and practitioners checked the draft questionnaire in terms of its applicability. As a result of the pilot study, the draft questionnaire was refined. The final questionnaire was sent to approximately 280 construction practitioners in the UK and the 
Republic of Ireland (ROI). As potential respondents, they were selected from main contractors, subcontractors and specialist contractors as well as LME suppliers that represented construction firms of different sizes across the UK and the ROI. All the respondents had more than five years of innovation-related work experience in the construction industry. Most of them held important management positions in construction firms, such as managing directors and senior managers, so that they had a good understanding of firm-level innovation. The survey resulted in the return of 64 completed questionnaires. The response rate was $22.9 \%$. Although the rate was not high, it was not uncommon for a construction survey.

\section{Analysis of questionnaire responses}

$90.6 \%$ of questionnaire responses were collected from different regions of the UK, such as England, Scotland and Northern Ireland. There were only $9.4 \%$ of responses from the ROI. Among the questionnaire responses, $51.6 \%$ were from micro/small firms; $23.4 \%$ from medium firms; and $25.0 \%$ from large firms. In the following sections, the three groups of construction firms are simply called small, medium and large firms in order to better compare them.

\section{Forces that drive innovation in construction firms of different sizes}

A potential driving force in Section 3 of the questionnaire can be considered as an innovation driver for a particular group if its mean is greater than 3. Table I shows 14 drivers of innovation for the small group; 15 drivers for the medium group; and 16 drivers for the large group. Generally, the larger the size of a firm is the more innovation drivers the firm has. The ranking, or the relative importance, of innovation drivers in each group is listed in Table I in terms of means comparison. There are a total of 13 common drivers, each of which is considered as a driver in all the three groups. Among the 13 common drivers, seven of them are internal, 
including H\&S improvement, pursuit of best practice, cost savings, sustainable construction, corporate image, development of competitive advantages, and growth of productivity. On the other hand, six common drivers are external: customer/user satisfaction, new business opportunities, market competition, changing business environments, client demands, and technological advances. As a result, the driving forces from internal and external sources are nearly balanced.

Table I. Innovation drivers for construction firms of different sizes

For general and construction innovation, driving forces can be either technology-push or marketpull (Dodgson et al., 2005; Barrett and Sexton, 2006). Among the drivers that are common for the three groups, technological advances relate to technology-push, whereas market-pull is characterized by new business opportunities, market competition, changing business environments, and client demands. Technological advances ranks last among the common drivers of innovation, which is lower than any of the four common drivers that characterize market-pull. All these may illustrate that market-pull has a greater effect on driving innovation in construction than technology-push. Compared to many other industry sectors, construction has a low-tech connotation (Harty, 2008). For this reason, it is not surprising that construction innovation is less driven by technological factors than by market factors. In other words, market is a more dominant driving force.

Traditionally, construction is oriented to the cost-driven philosophy (Dulaimi et al., 2002). According to the list of total means, cost savings rank fourth among the drivers of innovation 
that are common for the three groups. The ranking shows that cost savings still play an important role in driving innovation in all the three groups. On the other hand, it is inspiring that innovation in construction firms of different sizes is all driven now by $\mathrm{H} \& \mathrm{~S}$ improvement, customer/user satisfaction, and pursuit of best practice. H\&S improvement and customer/user satisfaction share the overall first place and pursuit of best practice ranks third overall. The top three common drivers characterize the value of innovation. As a result, it is evident that construction firms of different sizes have increasingly recognized the importance of value. A major change from costdriven innovation to value-driven innovation is observed in this research.

Although there are 13 drivers that are common for the three groups, the ranking of each common driver in one group may be different from that in another group. For example, cost savings rank first in the small group, third in the medium group, and thirteenth in the large group. The influence of cost savings on driving innovation is reduced step by step following the growth of firm size. Cost savings play the most important role in driving innovation for small firms. In other words, innovation in the small group is still most likely to be cost-driven. Although cost savings have importance for medium and large firms, this driver is no longer the first consideration. Among the common drivers in the large group, for example, H\&S improvement has the highest priority, which is followed by sustainable construction and customer/user satisfaction, all of which characterize the value of innovation.

Unlike the drivers that are common for the three groups, change in regulations and integration of design and construction can only drive innovation in the medium and large groups. Medium and large firms usually represent main contractors or design-build contractors. They have enough opportunities to collaborate with design teams to overcome the separation of design and construction. As subcontractors, specialist contractors and LME suppliers, small firms are less 
likely to collaborate with design teams directly. This explains why integrating design and construction is only identified as a driver of innovation in the medium and large groups. All construction firms have to comply with regulations no matter whether they are larger or smaller. In spite of that, change in regulations can only drive innovation in the medium and large groups because they have expertise in legal issues. According to the Business Enterprise Committee (BEC) of the House of Commons in the UK, the complexity of regulations creates difficulties for small construction firms (BEC, 2008). In the construction industry, small firms often struggle to keep up with legal changes and turn challenges into opportunities.

Survival and prosperity can only drive innovation in the small group, whereas global competition is only a driver of innovation in the large group. Both of them are only active in one particular group. The finding of survival and prosperity driving innovation in the small group provides quantitative evidence to support Sexton and Barrett (2003). Compared to medium and large firms, small firms are not strong enough. They are more sensitive to survival and prosperity. In order to survive and thrive, they have to actively adapt themselves to the ever changing world. On the other hand, small and medium firms generally work for local businesses and therefore they do not enter international construction markets. It is only possible for large construction firms to participate in global competition. In the face of increasing pressure from global competition, they have to develop competitive advantages continuously through innovation.

One-way analysis of variance (ANOVA) is used to examine the differences in means among the three groups. According to the results of ANOVA, there are significant differences of means for the following nine innovation drivers among the three groups:

- Survival and prosperity $(F=40.760 ;$ Sig. $=0.000)$

- Global competition $(F=26.569 ;$ Sig. $=0.000)$ 
- Cost savings $(F=14.609 ;$ Sig. $=0.000)$

- Change in regulations $(F=12.650 ;$ Sig. $=0.000)$

- Development of competitive advantages $(F=6.341$; Sig. $=0.003)$

- Integration of design and construction $(F=6.270 ;$ Sig. $=0.003)$

- Growth of productivity $(F=3.781 ;$ Sig. $=0.028)$

- $\quad$ Corporate image $(F=3.655 ;$ Sig. $=0.032)$

- Sustainable construction $(F=3.207$; Sig. $=0.047)$

On the other hand, government initiatives, government incentives and responses to economic recession are not identified as innovation drivers in any group. Although construction firms have to develop appropriate strategies in response to economic recession, responses to economic recession do not necessarily lead to innovation. Instead, economic recession may affect on-going innovation processes in construction firms due to financial difficulties. Furthermore, it is found that government initiatives and government incentives are not as effective for driving innovation as expected in construction firms. With regard to the government limitation, this research is consistent with some previous studies, such as Seaden and Manseau (2001). If change in regulations as an innovation driver in medium and large construction firms is taken into consideration, it is possible to find that construction innovation still stays at the basic level, which means that construction firms do not actively follow government initiatives and government incentives although they have to comply with mandatory regulations.

\section{Innovation strategies adopted by construction firms of different sizes}

Similar to an innovation driver, a potential strategic option in Section 4 of the questionnaire can be considered as an innovation strategy in a particular group if its mean is greater than 3 . Table II 
shows 13 strategies for innovation in the small group; 16 strategies in the medium group; and 14 strategies in the large group. By comparison, medium firms have three more strategies than small firms and two more strategies than large firms. The ranking of innovation strategies in each group is listed in Table II in terms of means comparison. A total of seven common strategies are found in this research, each of which is considered as a strategy in all the three groups. Compared to the number of common drivers, the number of common strategies is nearly halved. Although many forces can drive their innovation, construction firms of different sizes tend to adopt different innovation strategies that are more specific to their own circumstances.

Table II. Innovation strategies for construction firms of different sizes

The common strategies cover different aspects of innovation: technology, resource, marketing and management. For example, it is possible to look at continuous improvement of innovation performance, top management support, and encouragement of learning and innovation culture from the management perspective. On the other hand, both effective use of existing resources and matching resources to strategies are related to resources for innovation. In addition, enhancement of technical capabilities represents a technology strategy, whereas business vision characterizes a marketing strategy. Effective use of existing resources ranks first in the small group, fourth in the medium group, and thirteenth in the large group. The ranking of matching resources to strategies is second in the small group, eighth in the medium group, and fourteenth in the large group. Compared to larger firms, resources are scarce for smaller firms. In order to achieve strategic objectives of innovation, smaller firms have to pay much more attention to existing resources and make full use of existing resources. 
Unlike the seven strategies that are common for the three groups, the seven others are only adopted in the medium and large groups, among which education and training of employees, recruitment of new and skilled employees, and investment in R\&D are three strategies in relation to resources; moving from reactive to proactive innovation, focus on long-term benefits, and linking individual projects to overall businesses are three management strategies; and extension of business fields is a marketing strategy. The finding demonstrates that innovation in medium and large firms is characterized by resource investment, $R \& D$, marketing extension, strategic and long-term focus, and proactive management. In construction, small firms often pay closer attention to short-term benefits. If the rate of return is slow, they may lose interest in innovation. In contrast, medium and large firms are more interested in long-term benefits. Innovation needs various resources, such as money (financial resource) and people (human resource). It is medium and large firms that are able to invest in $R \& D$. In particular, investment in $R \& D$ ranks first in the large group. It is also medium and large firms that adopt strategies of staff recruitment and development to promote innovation.

On the other hand, it is found that five strategies are only adopted in small firms, including quick response to changing environments, making the right decision at the right time, establishment of incentive mechanisms, getting everyone involved in innovation and early identification of associated risks and uncertainties, all of which can be considered as management strategies. The finding suggests that small firms are much more agile for innovation. For example, small firms can quickly respond to changing environments in order to innovate. By comparison, medium and large firms are relatively slow in responding due to complex organizational structures and decision-making processes. People pursue innovation because it offers benefits (Akintoye et al., 2012). However, innovation per se is not always beneficial (Barrett and Sexton, 2006). 
Sometimes innovation is associated with risks (Loosemore, 2014). For this reason, early identification of associated risks and uncertainties is an important strategy for innovation in construction. The adoption of this strategy and the four others, such as quick response to changing environments, in small firms provides evidence that large and medium firms are not always superior to small firms in innovation. Instead, small construction firms have their own advantages in some areas of innovation.

Timely identification of the need for innovation is a strategy that is only adopted in small and medium firms. The complex structure and organizational rigidity of large firms may prevent them from timely identification of the need for innovation. Smaller construction firms prove to be more innovative in this particular area. Existing studies on general innovation, such as McAdam (2000) and Lööf and Heshmati (2002), and those on construction innovation, such as Egbu (2004) and Maqsood and Finegan (2009), believe that knowledge and knowledge management have an important contribution to innovation success. Knowledge can be viewed as intellectual resource of innovation. In spite of that, the adoption of knowledge exchange and sharing throughout the firm is only found in this research for medium firms. On the other hand, knowledge exchange and sharing between supply chain partners and knowledge transfer from universities and other R\&D establishments are two potential strategic options that are not generally adopted in any groups. According to the Department for Business Innovation and Skills (BIS) of the UK Government, construction businesses could gain greater exposure to new ideas and knowledge, and this would keep them at the front of on-going developments in innovation and technology (BIS, 2013). The construction industry today is more challenging than ever before. In order to ensure innovation success, there is a need for construction firms to better address knowledge exchange, sharing and transfer. 
Similar to money (financial resource) and people (human resource), knowledge (intellectual resource) is crucial for innovation. According to Eriksson (2013), both exploitation of existing knowledge and exploration of new knowledge should be highlighted for construction innovation. In this research, there are three potential innovation strategies in relation to knowledge and knowledge management: knowledge exchange and sharing throughout the firm, knowledge exchange and sharing between supply chain partners, and knowledge transfer from universities and other R\&D establishments. Knowledge acquisition can be either internal or external. Knowledge exchange and sharing throughout the firm is an internal source of knowledge acquisition. On the other hand, knowledge exchange and sharing between supply chain partners and knowledge transfer from universities and other R\&D establishments characterize two external sources of knowledge acquisition. The above finding indicates that, compared to internal knowledge acquisition, external knowledge acquisition is more unsuccessful in construction practice. For this reason, it is necessary for construction firms to place more emphasis on knowledge acquisition from both internal and external sources.

\section{Significant differences for innovation strategies among the three groups}

The test of ANOVA presents a total of 13 innovation strategies, for which there are significant differences of means among the three groups. Table III exhibits the relationship between the size of a firm and its likelihood to adopt a strategy for innovation. The positive relationship for a strategy shows that the larger a firm is the more likely it is to adopt this strategy for innovation, describing an ascending trend, whereas the negative relationship for a strategy characterizes a descending trend, indicating that the smaller a firm is the more likely it is to adopt this strategy for innovation. As shown in Table III, there is a positive relationship for six strategies, in which investment in $R \& D$ has the most significant difference among the three groups. On the other 
hand, a negative relationship is found for the other six strategies, in which quick response to changing environments is most significantly different among the three groups.

Table III. Innovation strategies with significant differences among the three groups

Almost all the innovation strategies that are significantly different among the three groups have either positive or negative relationships with firm size. Following the growth of firm size step by step, construction firms pay increasing or decreasing attention to these innovation strategies, respectively. In the literature on general innovation, Acs and Audertsch (1988) and Dosi (1988) identified a positive relationship between firm size and R\&D expenditure. Shefer and Frenkel (2005) did not concur with the previous two studies, but identified a negative relationship between firm size and the rate of investment in $R \& D$ for a group of high-tech firms. By comparison, the findings of this research are more meaningful in terms of construction innovation. It is because this research discovers both positive and negative relationships. It is also because this research introduces positive/negative relationships into many innovation strategies other than R\&D.

The cluster with a positive relationship, or with an ascending trend, includes almost all the strategies that are only adopted in the medium and large groups. Except for effective use of existing resources and matching resources to strategies that are common for the three groups, the cluster with a negative relationship, or with a descending trend, includes almost all the strategies that are only adopted in the small group. In the first strategic cluster, larger firms are significantly more innovative than smaller firms. In the second strategic cluster, smaller firms are 
significantly more innovative than larger firms. In addition, it is also possible for medium firms to be significantly more innovative than small and large firms, which can be seen from the following analysis of knowledge exchange and sharing throughout the firm.

In Table III, knowledge exchange and sharing throughout the firm is the only exception, for which both positive and negative relationships cannot be observed. A lack of ascending/descending trend is not rare in the literature on general innovation. For example, Bertschek and Entorf (1996) found a U-shaped relationship between firm size and R\&D capital per head. Unlike Bertschek and Entorf (1996), an inverted U-shaped relationship is found in this research between firm size and knowledge exchange and sharing throughout the firm. This strategy is only adopted in the medium group, whereas the adoption of this strategy in the small and large groups is not evident statistically. In small construction firms, knowledge is usually concentrated in a few staff members (Sexton and Barrett, 2003). On the other hand, the bureaucratic culture and conflicting interests between business units may inhibit knowledge transfer and sharing in a large construction firm (Robinson et al., 2005). All these help to explain why the inverted U-shaped relationship is found in this research to show the advantage of medium firms over small and large firms in terms of knowledge transfer and sharing throughout the firm.

\section{Conclusions}

Construction has started its journey to continuous innovation, which describes a change movement in the whole industry. In this research, 13 drivers and 7 strategies are identified, which are common for innovation in construction firms of different sizes. Based on the identification of common drivers and strategies, this research provides clear evidence for four common trends: (1) internal and external driving forces have the balanced influence on 
construction innovation; (2) construction innovation results from a combination of technologypush and market-pull, in which market-pull may be more effective than technology-push; (3) construction firms are moving from cost-driven innovation to value-driven innovation; and (4) construction firms adopt strategies in relation to technology, resource, marketing and management for innovation. Although common drivers and strategies are applicable to construction firms of different sizes, the relative importance of each common driver and strategy varies from one firm to another depending on firm size. For example, value-driven innovation is more important for larger firms than for smaller firms. Compared to larger firms, on the other hand, it is more important for smaller firms to strategize innovation through the effective use of existing resources.

It is found in this research that, unlike common drivers or strategies, some other drivers or strategies are specific to a particular size of construction firms. This means that the drivers or strategies for innovation in smaller firms may be different from those in larger firms. For example, innovation in small firms is likely to be driven by survival and prosperity, whereas innovation in large firms is likely to be driven by global competition. On the other hand, small firms tend to innovate through quickly responding to changing environments, whereas medium and large firms tend to innovate through focusing on long-term benefits. For this reason, it is not appropriate to say that one-sized firms are definitely more innovative than another-sized firms. Instead, larger firms are more innovative in some areas of innovation, whereas smaller firms are more efficient innovators in other areas. Both larger and smaller firms have their own advantages when pursuing best innovation practice.

The purpose of innovation is to enhance business performance. Firms benefit from performance improvement through continuous innovation. This research has theoretical and practical 
implications for construction innovation. On one hand, this research demonstrates that innovation is not the privilege of any particular size of construction firms. All construction firms can innovate regardless of firm size. As a result, every firm in construction has opportunities to make improvement through innovation. On the other hand, this research encourages construction firms of different sizes to realize what forces can better drive their innovation and what strategies are more appropriate for their innovation. That is to say, they should adopt different innovation patterns that best suit them. In doing so, it becomes possible for them to give full play to their own advantages in innovative practice. This is probably the best way of promoting innovation in the construction industry.

Although this research makes contributions to construction innovation, it contains some limitations. First of all, this research mainly targets the UK construction industry. The findings in this research are not necessarily universal. As a result, this research has a contextual limitation. Secondly, this research targets main contractors, subcontractors and specialist contractors as well as LME suppliers but excludes other types of project-based organizations in the construction industry, such as client organizations, design firms, and management consultants. In doing so, this research is simplified and becomes more focused. However, it is not possible to compare all types of project-based organizations in the construction industry in terms of innovation drivers and strategies. Further research is recommended to investigate innovation drivers and strategies in more countries and for a greater variety of project-based organizations. It is hoped that an investigation with a larger sample will lead to a more thorough and robust understanding of innovation drivers and strategies in construction firms. Since knowledge management remains challenging to construction firms, another recommendation is to pay further research attention to 
the role of knowledge exchange, sharing and transfer in promoting innovation for construction firms of different sizes.

\section{References}

Abdel-Wahab, M.S., Dainty, A.R.J., Ison, S.G., Bowen, P. and Hazlehurst, G. (2008), “Trends of skills and productivity in the UK construction industry", Engineering, Construction and Architectural Management, Vol. 15 No. 4, pp. 372-382.

Acs, Z.J. and Audertsch, D.B. (1988), "Innovation in large and small firms: an empirical analysis", American Economic Review, Vol. 78 No. 4, pp. 678-690.

Akintoye, A., Goulding, J. and Zawdie, G. (2012), Construction Innovation and Process Improvement, Blackwell, Oxford.

Aouad, G., Ozorhon, B. and Abbott, C. (2010), "Facilitating innovation in construction: directions and implications for research and policy", Construction Innovation, Vol. 10 No. 4, pp. 374-394.

Arditi, D., Kale, S. and Tangkar, M. (1997), "Innovation in construction equipment and its flow into the construction industry”, Journal of Construction Engineering and Management, Vol. 123 No. 4, pp. 371-378.

Barlow, J. (1999), "From craft production to mass customization: innovation requirements for the UK housebuilding industry", Housing Studies, Vol. 14 No. 1, pp. 23-42.

Barrett, P. and Sexton, M. (2006), "Innovation in small, project-based construction firms", British Journal of Management, Vol. 17 No. 4, pp. 331-346.

Bennett, J. (2013), Construction: The Third Way, Routledge, London.

Bertschek, I. and Entorf, H. (1996), “On nonparametric estimation of the Schumpeterian link between innovation and firm size: evidence from Belgium, France and Germany”, Empirical Economics, Vol. 21 No. 3, pp. 401-426.

Bossink, B.A.G. (2004), "Managing drivers of innovation in construction networks", Journal of Construction Engineering and Management, Vol. 130 No. 3, pp. 337-345. 
Business Enterprise Committee of House of Commons (2008), Construction Matters: Reports Together with Minutes, BEC, London.

Cassiman, B. and Veugelers, R. (2006), "In search of complementarity in innovation strategy: internal R\&D and external knowledge acquisition”, Management Science, Vol. 52 No. 1, pp. 68-82.

Chang, C.H. (2011), "The influence of corporate environmental ethics on competitive advantage: the mediation role of green innovation", Journal of Business Ethics, Vol. 104 No. 3, pp. 361-370.

Chartered Institute of Building (2007), Innovation in Construction: Ideas Are the Currency of the Future, CIOB, Ascot.

Chartered Institute of Building (2010), Code of Practice for Project Management for Construction and Development, Fourth Edition, Blackwell, Oxford.

Cohen, W.M. and Klepper, S. (1996), "Firm size and the nature of innovation within industries: the case of process and product R\&D”, Review of Economics and Statistics, Vol. 78 No. 2, pp. 232-243.

Crossan, M.M. and Apaydin, M. (2010), “A multi-dimensional framework of organizational innovation: a systematic review of the literature", Journal of Management Studies, Vol. 47 No. 6, pp. 1154-1191.

Davey, C.L., Powell, J.A., Cooper, I. and Powell, J.E. (2004), “Innovation, construction SMEs and action learning”, Engineering, Construction and Architectural Management, Vol. 11 No. 4, pp. 230-237.

Department for Business Innovation and Skills (2013) UK Construction: An Economic Analysis of the Sector, BIS, London.

Dewick, P. and Miozzo, M. (2004), "Networks and innovation: sustainable technologies in Scottish social housing”, R\&D Management, Vol. 34 No. 3, pp. 323-333.

Dodgson, M., Gann, D. and Salter, A. (2005), Think, Play, Do: Technology, Innovation, and Organization, Oxford University Press, Oxford.

Dosi, G. (1988), "Sources, procedures and microeconomic effects of innovation”, Journal of Economic Literature, Vol. 26 No. 3, pp. 1120-1171.

Dringoli, A. (2009), Creating Value through Innovation, Edward Elgar, Cheltenham. 
Dulaimi, M.F., Ling, F.Y.Y., Ofori, G. and Silva, N.D. (2002), "Enhancing integration and innovation in construction”, Building Research and Information, Vol. 30 No. 4, pp. 237-247.

Egbu, C.O. (2004), "Managing knowledge and intellectual capital for improved organizational innovations in the construction industry: an examination of critical success factors", Engineering, Construction and Architectural Management, Vol. 11 No. 5, pp. 301-315.

Eriksson, P.E. (2013), "Exploration and exploitation in project-based organizations: development and diffusion of knowledge at different organizational levels in construction companies", International Journal of Project Management, Vol. 31 No. 3, pp. 333-341.

European Commission (2005), The New SME Definition: User Guide and Model Declaration, EC, Brussels.

Gambatese, J.A. and Hallowell, M. (2011), "Factors that influence the development and diffusion of technical innovations in the construction industry", Construction Management and Economics, Vol. 29 No. 5, pp. 507-517.

Gann, D.M. and Salter, A.J. (2000), "Innovation in project-based, service-enhanced firms: the construction of complex products and systems", Research Policy, Vol. 29 No. 7-8, pp. 955-972.

Gerybadze, A., Hommel, U., Reiners, H.W. and Thomaschewski, D. (2010), Innovation and International Corporate Growth, Springer, Heidelberg.

Goffin, K. and Mitchell, R. (2005), Innovation Management: Strategy and Implementation Using the Pentathlon Framework, Palgrave Macmillan, Basingstoke.

Hardie, M. and Newell, G. (2011), "Factors influencing technical innovation in construction SMEs: an Australian perspective", Engineering, Construction and Architectural Management, Vol. 18 No. 6, pp. 618-636.

Hartmann, A. (2006a), "The context of innovation management in construction firms", Construction Management and Economics, Vol. 24 No. 6, pp. 567-578.

Hartmann, A. (2006b), "The role of organizational culture in motivating innovative behavior in construction firms", Construction Innovation, Vol. 6 No. 3, pp. 159-172. 
Harty, C. (2008), "Implementing innovation in construction: contexts, relative boundedness and actornetwork theory”, Construction Management and Economics, Vol. 26 No. 10, pp. 1029-1041.

Hewitt-Dundas, N. (2006), "Resource and capability constraints to innovation in small and large plants", Small Business Economics, Vol. 26 No. 3, pp. 257-277.

Hirsch-Kreinsen, H. and Jacobson, D. (2008), Innovation in Low-Tech Firms and Industries, Edward Elgar, Cheltenham.

Jassawalla, A.R. and Sashittal, H.C. (2002), "Cultures that support product-innovation processes", Academy of Management Perspectives, Vol. 16 No. 3, pp. 42-54.

Jepsen, L.B., Dell'Era, C. and Verganti, R. (2014), “The contributions of interpreters to the development of radical innovations of meanings: the role of 'Pioneering Projects' in the sustainable buildings industry", R\&D Management, Vol. 44 No. 1, pp. 1-17.

Kumar, K., Boesso, G., Favotto, F. and Menini, A. (2012), "Strategic orientations, innovation patterns and performances of SMEs and large companies", Journal of Small Business and Enterprise Development, Vol. 19 No. 1, pp. 132-145.

Kyrgidou, L.P. and Spyropoulou, S. (2013), "Drivers and performance outcomes of innovativeness: an empirical study", British Journal of Management, Vol. 24 No. 3, pp. 281-298.

Leiringer, R. (2006), "Technological innovation in PPPs: incentives, opportunities and actions", Construction Management and Economics, Vol. 24 No. 3, pp. 301-308.

Lim, J.N., Schultmann, F. and Ofori, G. (2010), “Tailoring competitive advantages derived from innovation to the needs of construction firms", Journal of Construction Engineering and Management, Vol. 136 No. 5, pp. 568-580.

Lööf, H. and Heshmati, A. (2002), "Knowledge capital and performance heterogeneity: a firm-level innovation study”, International Journal of Production Economics, Vol. 76 No. 1, pp. 61-85.

Loosemore, M. (2014), Innovation, Strategy and Risk in Construction: Turning Serendipity into Capability, Routledge, Abingdon. 
Magretta, J. (2012), Understanding Michael Porter: The Essential Guide to Competition and Strategy, Harvard Business Review Press, Boston.

Manley, K. and McFallan, S. (2006), "Exploring the drivers of firm-level innovation in the construction industry”, Construction Management and Economics, Vol. 24 No. 9, pp. 911-920.

Maqsood, T. and Finegan, A.D. (2009), "A knowledge management approach to innovation and learning in the construction industry", International Journal of Managing Projects in Business, Vol. 2 No. 2, pp. 297-307.

McAdam, R. (2000), "Knowledge management as a catalyst for innovation within organizations: a qualitative study", Knowledge and Process Management, Vol. 7 No. 4, pp. 233-241.

Miozzo, M. and Dewick, P. (2002), "Building competitive advantage: innovation and corporate governance in European construction”, Research Policy, Vol. 31 No. 6, pp. 989-1008.

Nam, C.H. and Tatum, C.B. (1997), "Leaders and champions for construction innovation", Construction Management and Economics, Vol. 15 No. 3, pp. 259-270.

Organization for Economic Cooperation and Development (1982), Innovation in Small and Medium Firms, OECD, Paris.

Ozaki, R. (2003), "Customer-focused approaches to innovation in housebuilding", Construction Management and Economics, Vol. 21 No. 6, pp. 557-564.

Panuwatwanich, K., Stewart, R.A. and Mohamed, S. (2008), "The role of climate for innovation in enhancing business performance: the case of design firms", Engineering, Construction and Architectural Management, Vol. 15 No. 5, pp. 407-422.

Pierce, J.L. and Delbecq, A.L. (1977), "Organization structure, individual attitudes and innovation", Academy of Management Review, Vol. 2 No. 1, pp. 27-37.

Porter, M.E. (1985), Competitive Advantage: Creating and Sustaining Superior Performance, Free Press, New York. 
Prajogo, D.I., McDermott, C.M. and McDermott, M.A. (2013), "Innovation orientations and their effects on business performance: contrasting small and medium-sized service firms", $R \& D$ Management, Vol. 43 No. 5, pp. 486-500.

Qi, G.Y., Shen, L.Y., Zeng, S.X. and Jorge, O.J. (2010), “The drivers for contractors' green innovation: an industry perspective", Journal of Cleaner Production, Vol. 18, No. 14, pp. 1358-1365.

Reichstein, T., Salter, A.J. and Gann, D.M. (2008), "Break on through: sources and determinants of product and process innovation among UK construction firms", Industry and Innovation, Vol. 15 No. 6, pp. 601-625.

Robinson, H.S., Carrillo, P.M., Anumba, C.J. and Al-Ghassani, A.M. (2005), "Knowledge management practices in large construction organizations", Engineering, Construction and Architectural Management, Vol. 12 No. 5, pp. 431-445.

Seaden, G. and Manseau, A. (2001), "Public policy and construction innovation", Building Research and Information, Vol. 29 No. 3, pp. 182-196.

Seaden, G., Guolla, M., Doutriaux, J. and Nash, J. (2003), "Strategic decisions and innovation in construction firms", Construction Management and Economics, Vol. 21 No. 6, pp. 603-612.

Sexton, M. and Barrett, P. (2003), “Appropriate innovation in small construction firms”, Construction Management and Economics, Vol. 21 No. 6, pp. 623-633.

Shefer, D. and Frenkel, A. (2005), "R\&D, firm size and innovation: an empirical analysis", Technovation, Vol. 25 No. 1, pp. 25-32.

Shelton, J., Martek, I. and Chen, C. (2016), "Implementation of innovative technologies in small-scale construction firms: five Australian case studies", Engineering, Construction and Architectural Management, Vol. 23 No. 2, pp. 177-191.

Steele, J. and Murray, M. (2004), "Creating, supporting and sustaining a culture of innovation", Engineering, Construction and Architectural Management, Vol. 11 No. 5, pp. 316-322.

Tatum, C.B. (1989), "Organizing to increase innovation in construction firms", Journal of Construction Engineering and Management, Vol. 115 No. 4, pp. 602-617. 
Thorpe, D., Ryan, N. and Charles, M.B. (2009), “Innovation and small residential builders: an Australian study", Construction Innovation, Vol. 9 No. 2, pp. 184-200.

Toole, T.M., Hallowell, M. and Chinowsky, P. (2013), “A tool for enhancing innovation in construction organizations", Engineering Project Organization Journal, Vol. 3 No.1, pp. 32-50.

Veshosky, D. (1998), "Managing innovation information in engineering and construction firms", Journal of Management in Engineering, Vol. 14 No. 1, pp. 58-66.

Wagner, E.R. and Hansen, E.N. (2005), "Innovation in large versus small companies: insights from the US wood products industry", Management Decision, Vol. 43 No. 6, pp. 837-850.

Wandahl, S., Jacobsen, A., Lassen, A.H., Poulsen, S.B. and Sørensen, H. (2011), "User-driven innovation in a construction material supply network", Construction Innovation, Vol. 11 No. 4, pp. 399-415.

Yadav, M.S., Prabhu, J.C. and Chandy, R.K. (2007), "Managing the future: CEO attention and innovation outcomes", Journal of Marketing, Vol. 71 No. 4, pp. 84-101.

Yitmen, I. (2007), "The challenge of change for innovation in construction: a North Cyprus perspective", Building and Environment, Vol. 42 No. 3, pp. 1319-1328. 